TEME, г. XLII, бр. 3, јул - септембар 2018, стр. 939-959

Прегледни рад

DOI: $10.22190 /$ TEME1803939K

Примљено: 26. 3. 2017.

UDK 330.52:336.61

Одобрено за штампу: 12. 6. 2018.

\title{
ИЗАЗОВИ И АЛТЕРНАТИВЕ ЗА ПОСТИЗАЮЕ ОДРЖИВОГ РАЗВОЈА ЗАШТИЋЕНИХ ПОДРУЧЈА И КОМОНСА У СРБИЈИ ОСЛОЊЕНИ НА ФИНАНСИЈСКУ АНАЛИЗУ И УПРАВЉАЧКЕ ОПЦИЈЕ ${ }^{a}$
}

\author{
Милица Кочовић ${ }^{1}$, Елена Јовичић ${ }^{1}$, Јасна Бабић \\ ${ }^{1}$ Институт економских наука, Београд, Србија \\ ${ }^{2}$ Универзитет у Београду, Економски факултет, Београд, Србија \\ milica.kocovic@ien.bg.ac.rs
}

\begin{abstract}
Апстракт
Предмет истраживања рада је фокусиран на алтернативе кроз препоруке за финансирање и управљање са циљем постизања одрживог развоја заштићених подручја и комонса. У раду је спроведена финансијска анализа пословања националних паркова, отворивши један од изазова за одрживи (економски и еколошки) развој заштићених подручја Србије. Са циљем оцене финансијског положаја и давања препорука које могу обезбедити одрживи развој националних паркова (уз фокус на НП Ђердап), узет је у обзир вишегодишњи период. Финансијска анализа која је спроведена у раду односи се на мерење финансијских перформанси, оцену финансијског положаја и ефикасности пословања националних паркова са посебним освртом на НП Ђердап и припадајуће комонсе (commons).

Основни циљ огледа се у сагледавању слабости (које могу довести до неликвидности и несолвентности НП Ђердап у будућем периоду) како би се на време предузеле адекватне мере за њихово отклањање и обезбедио његов одрживи развој. Други изазов који се отворио проистиче из суштинских сличности и разлика у погледу одговорности, управљања, заштите и права на ниво коришћења националних паркова, као примера заштићених подручја и припадајућег наслеђа као примера комонса. Различите перспективе у погледу на ове блиске феномене потврђују смер датих управљачких препорука.

У односу на уочене финансијске и управљачке изазове, циљ рада огледа се у препорукама за алтернативна системска решења кроз успостављање финансијске и управљачке одрживости националних паркова и припадајућег наслеђа.

Кључне речи: заштићена подручја, национални паркови, комонси, финансијска анализа, партиципативно управљање.

\footnotetext{
${ }^{a}$ Овај рад је део истраживачких пројекта: Изазови и перспективе структурних промена у Србији: стратешки правци економског усклађивања са захтевима ЕУ (шифра: ОИ 179015) и Европске интеграције и друштвено-економске промене привреде Србије на путу ка ЕУ (шифра: III 47009), које финансира Министарство просвете, науке и технолошког развоја Републике Србије.
} 


\title{
CHALLENGES AND ALTERNATIVES RELATED TO FINANCIAL ANALYSIS AND MANAGEMENT OPTIONS FOR ACHIEVING SUSTAINABLE DEVELOPMENT OF PROTECTED AREAS AND COMMONS IN SERBIA
}

\begin{abstract}
The subject of the research paper is focused on the recommendations for alternative financing and management with the aim of achieving sustainable development of protected areas and the commons. For the need of research paper we have conducted financial analysis of operations of the national parks, which pointed out one of the challenges for sustainable (economic and environmental) development of protected areas in Serbia. We have taken into account the multi-year period, with the aim of assessment of the financial position in order to give recommendations that may provide sustainable development of national parks. Financial analysis conducted in this paper refers to the measurement of financial performances, the financial position and operations efficiency of the national parks with particular emphasis on NP Djerdap and related commons.

The basic objective of this analysis is reflected in the consideration of weakness (which can lead to the illiquidity and insolvency of NP Đerdap in the future), with the goal of timely undertaking adequate measures for their elimination ensuring sustainable development. The second challenge is concerned with the essential similarities and differences in terms of management, responsibilities, protection, rights to use national parks as examples of protected areas, and the associated heritage as examples of commons. Different perspectives on these phenomena closely confirm the direction of management recommendations.

In relation to the identified financial and management challenges, the main objective of the paper is to give recommendations for an alternative system solutions that reflects through the establishment the financial and management sustainability of national parks and associated heritage.
\end{abstract}

Key words: $\quad$ protected areas, national parks, commons, financial analysis, participatory governance.

\section{УВОД}

Према ближој и новијој дефиницији, национални парк, као заштићено подручје, представља ,јасно дефинисани географски простор који је препознат, намењен и којим се управља путем правних или других ефикасних средстава са циљем дугорочног очувања природе са пратећим еко-системским и културним вредностима" (IUCN, 2008). Из саме дефиниције можемо сагледати значај одрживог развоја националних паркова због припадајућег наслеђа.

Појам комонс (енгл. commons) можемо схватити и користи као генерички појам (као што је тржиште или држава). Према мишљењу аутора Барнеса, комонси се односе на све поклоне које смо наследили или заједно створили (Barnes, 2006). Како аутор наводи, 
појам обухвата својства са две основне карактеристике: комонси су поклони и сви су дељени, односно заједнички. За разлику од личних поклона, комонсе добијамо као чланови заједнице (ваздух, вода, екосистеми, језици, музика, одмори, новац, права, наука, паркови, интернет и др.). У том смислу, аутор комонсе метафорично описује као реку која функционише у три притоке: природа, заједница, култура (Barnes, 2006).

У првом делу рада биће објашњен значај националних паркова као заштићених подручја и припадајућег наслеђа као комонса са циљем указивања на изазове релевантне за права на употребу и управљање у поменутим категоријама, која отварају изазове у погледу на практичне политичке управљачке опције.

У другом делу рада приказана је компаративна анализа финансијских показатеља националних паркова Србије са циљем сагледавања финансијског положаја НП Ђердап и могућих изазова у вези са његовом економском одрживошћу.

У трећем делу рада су предложене препоруке, које могу позитивно допринети уоченим изазовима: финансијској стабилности, употреби и управљању које за циљ имају да допринесу одрживости Националног парка Ђердап и припадајућих комонса.

Истраживачка питања рада су:

1) Уколико је највећи изазов националних паркова финансијски стуб одрживог развоја, са тенденцијом да угрози еколошки стуб, да ли је оваква ситуација сигнал за размишљање о новим (системским) решењима?

2) Да ли је више етичан модел онај који обезбеђује учешће локалне заједнице (као главног корисника) у процесу управљања добрима, који за циљ има да повеже ресурсе заштићених подручја?

3) Да ли су резултати овог истраживања добар разлог да се поново размотре алтернативе у финансирању и управљању?

\section{ОДНОС ФЕНОМЕНА НАЦИОНАЛНИХ ПАРКОВА КАО ЗАШТИЋЕНИХ ПОДРУЧЈА И ПРИПАДАЈУЋЕГ ПРИРОДНОГ И КУЛТУРНОГ НАСЛЕЂА КАО КОМОНСА}

Заштићена подручја, као културни артефакти, историјски дуго уживају заштиту као подручја од великог значаја за друштво. Историјски налази сведоче да су поједина подручја стављана под посебну заштиту у циљу очувања природних ресурса у Индији још пре два миленијума (Holdgate,1999, Кочовић 2017). Заштићена подручја у Европи успостављају се у време ренесансе, најпре у виду краљевских ловачких резервата, која касније постају отворена за јавност (Eagles, et al., 2002; Кочовић 2017). Талас изградње заштићених 
подручја у модерном смислу од стране „нових” нација у Сједињеним Америчким Државама, Канади, Аустралији, Новом Зеланду и Јужној Африци током XIX века попримио је глобалне размере у XX веку, када готово свака земља на својој територији издваја заштићена подручја и усваја одговарајућу правну регулативу која се њима бави (Phillips, 2004; Кочовић 2017).

Временом долази до еволуције идеје у вези са промишљањем о сврси заштићених подручја, од једноставног концепта великих, дивљих површина намењених уживању, па до идеје о заштити природе и промоцији културних вредности. У вези са претходним, значајан је развој еколошке науке током 60-их година претходног века и других хибридних дисциплина, које су довеле до ширег прихватања потребе за систематским приступом планирању и управљању природним и културним ресурсима. Истовремено је откривањем економског утицаја алтернативних форми туризма и тзв. bottom up приступа управљања заштићеним подручјима препознат њихов значај на локалном, регионалном и националном нивоу.

IUCN (1994) даје јединствену дефиницију заштићених подручја као површина земљишта и/или мора које су посебно посвећене заштити и одржавању биолошке разноврсности, као и природних и пратећих културних ресурса, и управљању њима путем правних и других ефикасних средстава. Према ближој и новијој дефиницији, заштићено подручје представља ,јасно дефинисани географски простор који је препознат, намењен и којим се управља путем правних или других ефикасних средстава са циљем дугорочног очувања природе са пратећим еко-системским и културним вредностима" (IUCN, 2008).

У циљу стандардизације дефинисања и управљања заштићеним подручјима, установљавају се одговарајући системи њихове категоризације. Актуелни систем IUCN обухвата шест категорија заштићених подручја: строге резервате природе, подручја дивљине, националне паркове, природне споменике или обележја, подручја управљања стаништем или врстом, заштићене копнене/морске просторе (пејзаже) и заштићена подручја са одрживим коришћењем природних ресурса (IUCN, 2008).

Закон о заштити животне средине који важи у Србији налаже правно-политичку регулацију када је у питању заштита предела. Према члану 26 поменутог закона:

„Заштита предела подразумева планирање и спровођење мера којима се спречавају нежељене промене, нарушавање или уништење значајних обележја предела, њихове разноврсности, јединствености и естетских вредности и омогућавање традиционалног начина коришћења предела. У планирању и уређењу простора, као и у планирању и коришћењу природних ресурса мора се обезбедити очување 
значајних и карактеристичних обележја предела" (Закон о заштити животне средине).

На заштићена подручја може се гледати и као на алат јавних практичних политика, који служи очувању вредности у ширем смислу. Неки аутори (Kitamura \& Clapp, 2013) шири вредносни смисао препознају кроз вредности као што су: биодиверзитет и пратеће пријатности које проистичу из коришћења. Заштићена подручја, као јавно-политички алат, обезбеђују влади контролу и мере рестрикције у погледу приступа и употребе над другим корисницима, у оквирима зона заштите. Будући да природна и културна добра, као саставни део заштићених подручја, у домаћој легислативи представљају уједно и јавна добра, то отвара потребу за испитивањем нових системских решења и управљачких опција, о којима ће више речи бити у трећем делу рада.

За Уго Матеија (2011) комонси траже значење. Они су контекстуализовани садржајем, који је у међусобној релацији са тражњом, улогама, потребама и рестрикцијама из друштвеног и политичког система (Mattei, 2011).

У погледу на управљачке односе, права на употребу, експлоатацију и одговорност, лежи суштинска разлика (али и сличности) између заштићених подручја и комонса као заједничких добара/имовине. Наиме, комонсима као заједничким добрима у теоријском смислу највећи број истраживања приступа у погледу на право и степен употребе/експлоатације (копнених и морских подручја) и препознаје управљања од стране заједнице. У великом броју истраживања, акценат је на тзв. bottom up приступу управљања и инклузивности, која је ослоњена на њихову фундаментално колективистичку природу.

За заштићена подручја дефинисане су практичне политике управљања, са циљем заштите и ограничавања мера употребе/експлоатације. Можемо приметити релацију рестрикција версус инклузија у погледу на кључне феномене. Заштићена подручја углавном се налазе на јавним површинама, па су управљачи на примеру националних паркова Србије јавна предузећа. Иако постоји велики број успешних светских практичних примера међусекторских партнерстава са циљем оптималне употребе ресурса, а не нужне рестрикције над њима, у Србији практично међусекторско повезивање и даље није нарочито развијено. Кривошејев (2014) наводи примере који указују на случајеве када су у улози управљача других видова заштићених подручја различита јавна предузећа, нпр.: Србија шуме, као и јавна комунална предузећа, или када се ЈП оснива са циљем управљања питања из више ресора. Постоје примери заштићених подручја за која су наменски основана привредна друштва, док је, на пример, установа Туристичка организација Чачка одређена за управљача заштићеног подручја „Овчарско-кабларска клисура”, а постоје и при- 
мери где удружења грађана управљају заштићеним подручјима, углавном ловачка удружења, групе грађана и љубитељи природе (Кривошејев, 2014). Без обзира на то ко је у улози управљача заштићеним подручјима, држава мора обезбедити услове за примену ефикасног модела њиховог одрживог развоја.

Изазови са којима се суочавамо, посебно на пољу угрожене животне средине, кроз еколошку деградацију и климатске промене, доводе у питање одрживи развој заштићених подручја са припадајућим наслеђем (комонсима). Заједнички ресурси су наша заједничка одговорност и неопходно је наћи што више алтернативних могућности за њихово очување директним партиципирањем како би одрживи развој био осигуран.

Стога је следећи део рада посвећен анализи финансијског положаја националних паркова да би се сагледало тренутно стање, изазови и могућности уз препоруке за обезбеђење њиховог одрживог развоја.

\section{АНАЛИЗА ФИНАНСИЈСКОГ ПОЛОЖАЈА НАЦИОНАЛНИХ ПАРКОВА У СРБИЈИ}

У оквиру финансијске анализе, применом различитих техника, подаци из финансијских извештаја предузећа претварају се у информације значајне за управљање пословањем. Финансијски положај предузећа одређен је стањем финансијске равнотеже, задужености, солвентности и реалном вредношћу сопственог капитала (Тушевљак $\&$ Родић, 2003). Као такав, финансијски положај има за циљ да изрази обим и структуру средстава и капитала, као и њихове међуодносе који су исказани у билансу стања и билансу успеха националних паркова. Поред ова два извештаја, такође се користи и извештај о новчаним токовима, који обухвата приливе и одливе готовине.

\section{Стање финансијске равнотеже националних паркова}

У анализи финансијског положаја предузећа најзначајније место заузима анализа финансијске равнотеже, која је директно повезана са начелом стабилности финансијске политике. Фокус ове анализе је на усклађености рочности извора финансирања и средстава предузећа. Предузеће се налази у стању финансијске равнотеже уколико су обим и рокови везивања средства предузећа једнаки обиму и времену расположивости извора. Као извор података за ову анализу користе се биланси стања предузећа за најмање три претходна обрачунска периода. На примеру националних паркова у Србији, анализирана је дугорочна и краткорочна финансијска равнотежа. 
Оцена краткорочне финансијске равнотеже врши се стављањем у однос ликвидних и краткорочних средства, са једне стране, и краткорочних обавеза, са друге стране. Краткорочна финансијска равнотежа постоји ако је овај однос једнак јединици. У Табели 1 приказани су односи краткорочне финансијске равнотеже националних паркова Србије.

Табела 1. Очена краткорочне финансијске равнотеже НП Ђердап, Фрушка гора, Копаоник и Тара

\begin{tabular}{llllll}
\hline & 2011. & 2012. & 2013. & 2014. & 2015. \\
\hline Национални парк Ђердап & 0,419 & 0,456 & 0,575 & 0,546 & 0,665 \\
Национални парк Фрушка гора & 0,738 & 0,594 & 0,429 & 0,328 & 0,337 \\
Национални парк Копаоник & 1,527 & 2,283 & 1,848 & 2,789 & 5,056 \\
Национални парк Тара & 0,211 & 0,249 & 0,365 & 0,439 & 0,447 \\
\hline \multicolumn{4}{c}{ Извор: Рачунање аутора на основу података из биланса стања } \\
преузетих са сајта www.apr.gov.rs
\end{tabular}

Однос краткорочно везаних средстава и краткорочних извора финансирања НП Ђердап у посматране четири године кретао се у интервалу 0,419-0,665, односно краткорочно везана средства била су знатно мања од краткорочних извора финансирања. На основу наведених показатеља, може се закључити да НП Ђердап у посматраном периоду није обезбедио краткорочну финансијску равнотежу, тј. покриће краткорочних обавеза.

Имајући у виду специфичност пословања (јавних предузећа) националних паркова, непокривене краткорочне обавезе не морају бити показатељ који угрожава опстанак организације. Стога је потребно да се изврши поређење пословања НП Ђердап са пословањем остала три национална парка за које поседујемо информације на основу биланса стања и биланса успеха.

Из Табеле 1 види се да је једино НП Копаоник обезбедио краткорочну финансијску равнотежу (рацио вредност преко 1 , у посматраним годинама). Анализа дугорочне финансијске равнотеже предузећа значајна је због будућих пројекција и контроле, са циљем обезбеђивања ликвидности. Коефицијент дугорочне равнотеже добијен је стављањем у однос дугорочно везане имовине и трајног и дугорочног капитала. Претпоставка је да је финансијска равнотежа успостављена уколико је овај коефицијент једнак јединици. Када су квалитетни извори финансирања већи од дугорочно везаних средстава (тј. при вредности коефицијента мањој од 1), створена је сигурност за одржавање ликвидности на дуги рок.

У Табели 2 дати су израчунати коефицијенти дугорочне финансијске равнотеже националних паркова Србије. 
Табела 2. Очена дугорочне финансијске равнотеже НП Ђердап, Фрушка гора, Копаоник и Тара

\begin{tabular}{lllllr}
\hline НП & 2011. & 2012. & 2013. & 2014. & 2015. \\
\hline Национални парк Ђердап & 1,012 & 1,014 & 1,010 & 1,009 & 1,005 \\
Национални парк Фрушка гора & 1,014 & 1,020 & 1,032 & 1,043 & 1,045 \\
Национални парк Копаоник & 0,999 & 0,997 & 0,997 & 0,996 & 0,995 \\
Национални парк Тара & 1,016 & 1,010 & 1,010 & 1,006 & 1,06 \\
\hline \multicolumn{5}{c}{ Извор: Рачунање аутора на основу noдamaка из биланса стањa } \\
nреузетих са cajma www.apr.gov.rs
\end{tabular}

Коефицијент дугорочне финансијске равнотеже НП Ђердап је у посматраним годинама био већи од један. Иако одступања од референтне вредности нису значајна, може се ипак закључити да национални парк није створио услове за одржавање сталне ликвидности у дугом року. Коефицијент дугорочне финансијске равнотеже је у посматраним годинама био мањи од 1 једино код НП Копаоник. То значи да је једино овај национални парк у посматраном периоду створио услове за одржавање сталне ликвидности. Моделу Националног парка Копаоник требало би да теже и остали национални паркови.

\section{Ликвидност начионалних паркова}

Ликвидност се дефинише као способност предузећа да (расположивом ликвидном имовином) обезбеди измиривање доспелих краткорочних обавеза. Неки од основних показатеља ликвидности које у склопу континуираног праћења ликвидности треба рачунати су: коефицијент опште (текуће) ликвидности, коефицијент убрзане ликвидности и коефицијент тренутне. Коефицијент текуће ликвидности показатељ је ликвидности највишег степена, јер се добија као однос обртне имовине и краткорочних обавеза, односно покрића и потреба за капиталом у року од године дана. Овај показатељ мери способност предузећа да подмири своје краткорочне обавезе. Задовољавајућа вредност коефицијента текуће ликвидности је она која не одступа значајно од сектора, а уколико секторски просек није познат, тада би коефицијент опште ликвидности требало бити већи од 2. Коефицијент убрзане ликвидности добија се као однос обртних средстава умањених за залихе и краткорочних обавеза. Коефицијент убрзане ликвидности омогућава да се доносе закључак о томе да ли предузеће има довољно краткорочних средстава да подмири доспеле обавезе без продаје залиха. Као и код коефицијента текуће ликвидности, пожељна вредност овог показатеља је она која не одступа значајно од просека сектора. Уколико секторски просек није познат, вредност коефицијента убрзане ликвидности треба да буде минимално једнака 1. 
Коефицијент новчане ликвидности утврђује се стављањем у однос новчаних средстава и текућих обавеза. Обично предузећа не теже да располажу имовином у готовини и новчаним еквивалентима у толикој мери да обезбеде у потпуности измирење доспелих краткорочних обавеза. Отуда је овај показатељ по правилу мањи од један. Стандардно правило је да се вредност овог показатеља креће до висине 0,5 коефицијента тренутне ликвидности (Малешевић \& Вранковић 2007). Наведена рација за четири национална парка Србије израчуната су и приказана у Табели 3 . Може се закључити да је, за разлику од остала три парка, НП Копаоник у периоду 2011-2015. године имао ликвидност на задовољавајућем нивоу.

Табела 3. Показатељи ликвидности НП Бердап, Фрушка гора, Копаоник и Тара

\begin{tabular}{lccccc}
\hline & 2011. & 2012. & 2013. & 2014. & 2015. \\
\hline Коефицијент опште (текуће) ликвидности & & & & \\
\hline Национални парк Ђердап & 0,604 & 0,532 & 0,604 & 0,634 & 0,731 \\
Национални парк Фрушка гора & 1,142 & 0,912 & 0,829 & 0,749 & 0,724 \\
Национални парк Копаоник & 1,842 & 2,562 & 2,012 & 2,866 & 5,312 \\
Национални парк Тара & 0,864 & 0,582 & 0,724 & 0,992 & 1,097 \\
\hline Коефицијент убрзане ликвидности & & & & & \\
\hline Национални парк Ђердап & 0,403 & 0,445 & 0,563 & 0,515 & 0,647 \\
Национални парк Фрушка гора & 0,729 & 0,582 & 0,415 & 0,319 & 0,324 \\
Национални парк Копаоник & 1,508 & 2,208 & 1,823 & 2,820 & 4,472 \\
Национални парк Тара & 0,210 & 0,244 & 0,361 & 0,430 & 0,443 \\
\hline Коефицијент тренутне ликвидности & & & & & \\
\hline Национални парк Ђердап & 0,099 & 0,126 & 0,091 & 0,231 & 0,427 \\
Национални парк Фрушка гора & 0,264 & 0,287 & 0,235 & 0,147 & 0,133 \\
Национални парк Копаоник & 0,759 & 0,934 & 0,841 & 0,698 & 2,139 \\
Национални парк Тара & 0,004 & 0,029 & 0,127 & 0,091 & 0,097 \\
\hline
\end{tabular}

Извор: Рачунање аутора на основу података из биланса стања

nреузетих са cajma www.apr.gov.rs

\section{Анализа имовинског положаја националних паркова}

Имовински положај националних паркова ће бити анализиран на основу:

1. анализе структуре (структура укупне активе, структура пословне активе и структура оперативне активе);

2. анализе фиксне имовине (структура фиксне имовине, дотрајалост фиксне имовине, техничка опремљеност и искоришћење капацитета); на обрта);

3. анализе обртне имовине (структура обртне имовине и брзи-

4. анализе обрта пословне имовине и рока повраћаја. 
Када се анализира структура обртне имовине, обртна имовина се групише према степену ликвидности, односно према брзини трансформације појединих облика обртне имовине у готовину.

У Табели 4 приказано је кретање пословне имовине и биолошких средстава и учешће биолошких средстава у пословној имовини националних паркова.

Табела 4. Учешће биолошких средстава у пословној имовини НП Ђердап, Фрушка Гора, Копаоник и Тара (апсолутне вредности су исказане у хиьадама динара)

\begin{tabular}{|c|c|c|c|c|c|c|}
\hline & & 2011. & 2012. & 2013. & 2014. & 2015. \\
\hline \multirow{4}{*}{$\begin{array}{l}\text { Национални } \\
\text { парк Ђердап }\end{array}$} & 1. Пословна & 4.438 .326 & 4.469 .254 & 4.579 .094 & 4.500 .437 & 4.784 .235 \\
\hline & имовина & & & & & \\
\hline & $\begin{array}{l}\text { 2. Биолошка } \\
\text { средства }\end{array}$ & 4.226 .642 & 4.244 .100 & 4.248 .383 & 4.232 .360 & 4.233 .043 \\
\hline & $(2 / 1) \%$ & $95,23 \%$ & $94,96 \%$ & $92,78 \%$ & $94,04 \%$ & $94,04 \%$ \\
\hline \multirow{4}{*}{$\begin{array}{l}\text { Национални } \\
\text { парк } \\
\text { Фрушка гора }\end{array}$} & 1. Пословна & 2.864 .450 & 2.547 .804 & 2.477 .892 & 2.513 .877 & 2.381 .181 \\
\hline & имовина & & & & & \\
\hline & 2. Биолошка & 1.398 .390 & 1.235 .830 & 1.189 .533 & 1.200 .501 & 1.131 .045 \\
\hline & $(2 / 1) \%$ & $48,82 \%$ & $48,51 \%$ & $48,01 \%$ & $47,75 \%$ & $47,75 \%$ \\
\hline \multirow{4}{*}{$\begin{array}{l}\text { Национални } \\
\text { парк } \\
\text { Копаоник }\end{array}$} & 1. Пословна & 3.637 .557 & 3.644 .992 & 3.652 .680 & 3.652 .680 & 3.655 .518 \\
\hline & имовина & & & & & \\
\hline & 2. Биолошка & 3.571 .732 & 3.571 .732 & 3.571 .887 & 3.574 .278 & 3.574 .565 \\
\hline & & $98,35 \%$ & $97,99 \%$ & $97,79 \%$ & $97,85 \%$ & $97,85 \%$ \\
\hline \multirow{3}{*}{$\begin{array}{l}\text { Национални } \\
\text { парк Тара }\end{array}$} & 1. Пословна & 8.166 .598 & 8.151 .671 & 8.176 .863 & 8.165 .159 & $8.158 .041,00$ \\
\hline & 2. Биолошка & 7.818 .865 & 7.825 .494 & 7.828 .297 & 7.827 .985 & $7.824 .067,00$ \\
\hline & $(2 / 1) \%$ & $95,74 \%$ & $96,00 \%$ & $95,74 \%$ & $95,87 \%$ & $95,87 \%$ \\
\hline
\end{tabular}

Биланси стања сва четири национална парка показују да се вредност пословне имовине није у значајнијој мери мењала у периоду 2011-2015. године. Значајно учешће у пословној активи националних паркова имају биолошка средства. Биолошка средства обухватају шуму и вишегодишње засаде, док у НП Фрушка гора, поред шуме и вишегодишњих засада, један мањи део биолошких средстава обухвата основно стадо. За разлику од остала три, НП Фрушка гора у пословној активи има значајно учешће некретнина, постројења и опреме. На основу података из напомена уз финансијске извештаје, може се закључити да у оквиру ове ставке биланса стања највеће учешће имају земљишта. 
Посматрајући вредност пословне имовине и површине националних паркова, може се закључити да НП Ђердап има најмању вредност пословне имовине по хектару.

Табела 5. Пословна имовина по хектару у НП Бердап, Фрушка Гора, Копаоник и Тара

\begin{tabular}{lcrrrrr}
\hline \multirow{2}{*}{ Национални парк } & \multirow{2}{*}{$\begin{array}{c}\text { Површина } \\
\text { (хектара) }\end{array}$} & \multicolumn{5}{c}{ Однос пословне имовине (у 000 динара) } \\
\cline { 3 - 7 } & & 2011. & 2012. & 2013. & 2014. & 2015. \\
\hline Ђердап & $63.786,48$ & 69,58 & 70,07 & 71,79 & 70,55 & 75,00 \\
Фрушка гора & $26.672,00$ & 107,40 & 95,52 & 92,90 & 94,25 & 89,28 \\
Копаоник & $11.969,04$ & 303,91 & 304,54 & 305,18 & 305,18 & 305,41 \\
Тара & $24.991,82$ & 326,77 & 326,17 & 327,18 & 326,71 & 326,43 \\
\hline
\end{tabular}

Извор: Рачунање аутора на основу података из биланса стања преузетих са cajma www.apr.gov.rs

Укупан капитал националних паркова у 2015. години износио је 18.527.992 хиљада динара (Табела 6).

Табела 6. Капитал начионалних паркова (2011-2015) (у хиљадама динара)

\begin{tabular}{|c|c|c|c|c|c|}
\hline & 2011. & 2012. & 2013. & 2014. & 2015. \\
\hline $\begin{array}{l}\text { Национални парк } \\
\text { Ђердап }\end{array}$ & 4.333 .098 & 4.338 .119 & 4.445 .337 & 4.387 .187 & 4.691 .254 \\
\hline $\begin{array}{l}\text { Национални парк } \\
\text { Фрушка гора }\end{array}$ & 2.677 .559 & 2.384 .845 & 2.319 .562 & 2.320 .097 & 2.190 .487 \\
\hline $\begin{array}{l}\text { Национални парк } \\
\text { Копаоник }\end{array}$ & 3.603 .256 & 3.606 .557 & 3.610 .312 & 3.609 .838 & 3.615 .207 \\
\hline Национални парк Тара & 8.007 .644 & 8.007 .198 & 8.015 .757 & 8.024 .301 & 8.031 .044 \\
\hline Укупни капитал & 18.621 .557 & 18.336 .719 & 18.390 .968 & 18.340 .207 & 18.527 .992 \\
\hline
\end{tabular}




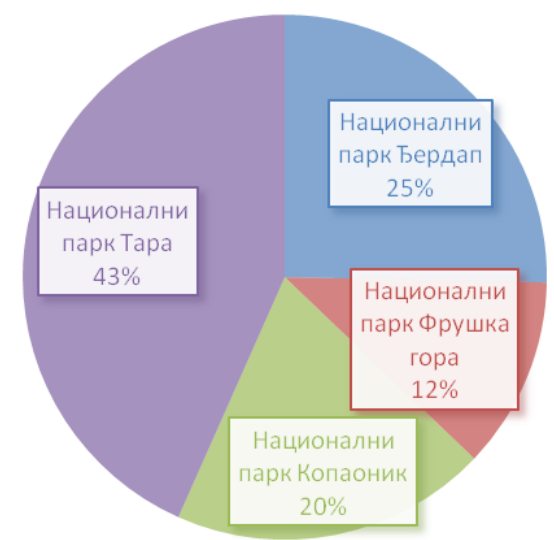

\section{Графикон 1. Удео капитала националних паркова \\ Извор: Рачунање аутора на основу података \\ из биланса стањ преузетих са сајma www.apr.gov.rs}

У укупном капиталу исказаном у финансијским извештајима на дан 31. 12. 2015. године националних паркова Србије, највеће учешће има НП Тара са $43 \%$, затим следе НП Ђердап са учешћем од $25 \%$, НП Копаоник са учешћем од $20 \%$ и НП Фрушка гора са учешћем од $12 \%$ (Графикон 1).

\section{Профитабилност националних паркова}

Профитабилност националних паркова биће оцењена на основу коефицијента профитабилности, као односа нето добитка (губитка) и укупног прихода. Он представља меру финансијских перформанси компаније и њене способности да повећа вредност капитала и генерише профит, а његове израчунате вредности за посматране националне паркове су приказане у Табели 7.

Табела 7. Коефииијент профитабилности националних паркова (2011-2015)

\begin{tabular}{llllll}
\hline & 2011. & 2012. & 2013. & 2014. & 2015. \\
\hline Национални парк Ђердап & 0,013 & 0,032 & 0,015 & 0,018 & 0,036 \\
Национални парк Фрушка гора & 0,001 & 0,002 & 0,002 & 0,004 & 0,008 \\
Национални парк Копаоник & 0,010 & 0,029 & 0,047 & 0,041 & 0,069 \\
Национални парк Тара & 0,004 & 0,005 & 0,010 & 0,031 & 0,044 \\
\hline
\end{tabular}

Извор: Рачунање аутора на основу података из биланса стања преузетих са cajma www.apr.gov.rs

У посматраним периоду национални паркови су остваривали позитивне резултате пословања. Национални парк треба да обезбеди одговарајућу добит како би обезбедио неопходне инвестиције. Сто- 
га, иако се ради о јавном предузећу, које има одређене државне субвенције, требало би да тежи остваривању што веће добити у складу са начелима одрживог развоја. Алтернативе у остваривању добити управо се огледају кроз развој нових делатности, на пример, еко-културног туризма, у чијој понуди могу да се нађу комонси на територији националних паркова.

Табела 8. Остварена добит у НП

Ђердап, Фрушка гора, Копаоник и Тара

\begin{tabular}{|c|c|c|c|c|c|}
\hline & 2011. & 2012. & 2013. & 2014. & 2015. \\
\hline \multicolumn{6}{|c|}{ 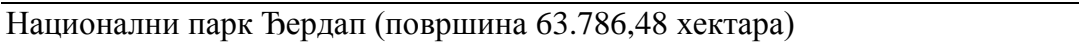 } \\
\hline Добит (000 динара) & 2.240 & 5.178 & 2.394 & 4.849 & 6.444 \\
\hline \multicolumn{6}{|c|}{ Национални парк Фрушка гора (површина 26.672,00 хектара) } \\
\hline Добит (000 динара) & 260 & 840 & 935 & 1.623 & 3.159 \\
\hline \multicolumn{6}{|c|}{ Национални парк Копаоник (површина 11.969,04 хектара) } \\
\hline Добит (000 динара) & 1.185 & 3.893 & 5.702 & 5.171 & 7.955 \\
\hline \multicolumn{6}{|c|}{ Национални парк Тара (површина 24.991,82 хектара) } \\
\hline Добит (000 динара) & 1.510 & 1.826 & 3.415 & 10.935 & 14.854 \\
\hline
\end{tabular}

Национални паркови су, након остваривања добити, у обавези да $50 \%$ врате држави, $50 \%$ задржавају, с тим да $30 \%$ морају да инвестирају у пословање, а $20 \%$ имају право да распореде на плате запослених. Највећу добит у 2015. години имао је НП Тара, а затим НП Копаоник.

На основу података из Табеле 8 , може се закључити да НП Ђердап има површину која је већа за 153,62 хектара од збирне површине сва три остала парка.

Информације добијене анализом представљају полазну основу за предузимање акција усмерених на поправљање бонитета и тренда раста и развоја пословања националних паркова. Да би се обавила поуздана анализа пословања националних паркова, неопходно је обезбедити исправност података, односно потребно је да књиговодствени и други подаци о пословању буду састављени и представљени у складу са важећим прописима, да буду исправни и објективни. Такође је неопходна једнообразност података. Поређењем елемената финансијских извештаја у претходних пет година омогућено је доношење закључка у вези са кретањем финансијских показатеља кроз посматрани период, на основу чега је могуће препознати проблематична подручја пословања.

На основу спроведене финансијске анализе, могуће је закључити да функционисање националних паркова јавних предузећа, као управљача заштићеним подручјима, умногоме зависи од будућих тежњи за успостављањем одрживог финансијског пословања. Поред 
бриге о комонсима (природна и културна добра, одрживости биодиверзитета и културне разноликости), формални управљачи - као јавна предузећа - имају само део за основно обављање делатности, кроз државне субвенције. Након остварене добити, 50\% враћају у буџет Републике Србије. При томе, треба имати у виду да је основно пословање и начин за стицање добити углавном ослоњен на природне ресурсе - дрво. Наметнутим притисцима кроз очекивања од стране државе (за остваривање профитабилног пословања) управљачи зарад постизања финансијске одрживости (на рачун реалних ресурса сечом шума) могу упасти у замку и угрозити основни смисао заштите и постојања ових јединствених подручја. Овај сценарио отвара проблем и међурелацију стубова одрживог развоја која се огледа у постизању економске одрживости, ослањањем на заштићене ресурсе. Поменути сценарио паралелно отвара питања етике, балансираног развоја и права на употребу.

Питања и дискусија у вези са претходним могу бити развијани кроз неколико паралелних смерова:

1) Ако је највећи изазов националних паркова финансијски стуб одрживог развоја, са тенденцијом да угрози еколошки стуб, да ли је оваква ситуација сигнал за размишљање о новим (системским) решењима?

2) Ако национални парк као јавна компанија допусти угроженост еколошког стуба одрживог развоја зарад пружања краткорочног опстанака, да ли се овакав развој може сматрати избалансираним, етичким и одрживим?

3) Да ли је више етичан модел који обезбеђује учешће локалне заједнице (као главног корисника) у процес управљања добарима, који за циљ има да повеже ресурсе заштићених подручја?

4) Да ли су резултати овог истраживања добар разлог да се поново размотре алтернативе у финансирању и управљању?

Треба имати у виду да режими који се тичу управљања екстрактивним ресурсима уобичајено треба да покрију трошкове менаџмента, мониторинга и спровођења активности, посебно у контексту тзв. bottom up приступа. Оно што се дешава код већине јавних предузећа (тзв. top down приступ) као управљача заштићеним подручјима јесте да поменути трошкови делимично јесу покривени из екстерних (буџетска средства) извора, а не кроз основно пословање и приходе од посета. Буџетске субвенције са једне стране недовољне су за одрживо функционисање заштићених подручја, а са друге стране, будући да долазе из пореских прихода, представљају терет за јавност, која нема увек јасне или директне користи од (сервисирања трошкова) заштићених подручја.

Када узмемо у обзир све трошкове: конзервације, управљања, пословања јавних предузећа која су формални управљачи заштиће- 
ним подручјима, јасно је да је немогуће бити ослоњен искључиво на буџетска средства, јер их поменути трошкови превазилазе. Надовезујући се на претходно, ауторка Остром и група аутора (Poteet \& Ostrom, 2004; Ostrom, 2009) наводе да када би поменуте укупне трошкове било могуће распоредити равномерније на кориснике и интересне групе, који се обавезују на међусобни мониторинг, контролне мере и санкције, тада би се могло говорити о правичнијим друштвеним институцијама које су уједно и ефикасне и ефективне.

Уколико се друге могућности огледају у укључивању осталих сектора, Кочовић сматра да би држава требало да покаже заинтересованост и за почетак да се одрекне $50 \%$ остварених прихода НП у Србији (Кочовић, 2017). Уместо да након остварене добити поменута средства буду враћена у буџет, ова средства могу се усмерити на посебан инвестициони фонд за развој друштвено-одговорних делатности на територији заштићених подручја (еко-културни туризам, социјално предузетништво, стари занати, производи локалног становништва и сл.). Могуће је, дакле, у оквиру НП формирати наменски фонд за поменуте сврхе или у оквиру локалне самоуправе, са циљем успостављања одрживијег модела финансирања пословања НП. Пожељно је укључивање и других заинтересованих страна из различитих сектора, тада говоримо о мешовитим моделима финансирања који су популарни када је реч о јавним и заједничким добрима.

\section{ПАРТИЦИПАТИВНО УПРАВЉАЬЕ КАО АЛТЕРНАТИВНО СИСТЕМСКО РЕШЕЊЕ ЗА УПРАВЉАЬЕ ЗАШТИЋЕНИМ ПОДРУЧЈИМА И КОМОНСИМА}

Партиципативно управљање заштићеним подручјима и комонсима је начин за обезбеђивање новог ефективнијег и ефикаснијег системског решења у односу на постојеће (Кочовић, 2017). Партиципативно управљање за циљ има да обезбеди већу транспарентност, децентрализацију, деетатизацију и демократичност у активностима подршке за циљем финансирања, управљања, употребе и дугорочног очувања заштићених подручја и припадајућих комонса. У својој суштини, партиципативно управљање кроз стратешка партнерства може довести до већег повезивања свих сектора. У том смислу, поред јавног, отвара се простор за укључивање приватног и цивилног сектора у процесе управљања. Добробити које произлазе из партнерстава и веће међусекторске сарадње огледају се најпре кроз предности и мане свих сектора, које су на овај начин међусобно комплементарне, обезбеђујући веће шансе за одрживост заштићених подручја и комонса.

Многи аутори сматрају да је у процесе управљања заштићеним подручјима неизоставно важно интегрисати локалну заједницу. 
Коришћење заштићених подручја не би требало да искључује заједницу, већ да је максимално интегрише, све док је употреба одржива и не изазива дисбаланс. Поједини аутори наводе опасности искључивања локалне заједнице у случајевима јавног управљања заједничким подручјима. Наиме, аутохтоно становништво које је од почетка политички и економски у неповољној позицији, често трпи искључивање са подручја у погледу на право на приступ, употребу и одлучивање у вези са заштићеним подручјима и комонсима (Cronon, 1995; Colchester, 1996; Neumann, 1999; Zimmerer, 2000; Hazen \& Harris, 2007; GarciaFrapolli et al., 2009; Kitamura \& Clapp, 2013). Можемо сматрати да ова ситуација произлази из строгих правила у погледу на зонирање и непостојање правила у погледу на комонсе. У том смислу, Хес (2001) наводи пример модела Yellowstone националног парка, који представља државну експропријацију почетно племенске земље. Заједница која је пре проглашења живела у оквирима морала је да напусти дотадашњи начин живота (Hess, 2001; Kitamura \& Clapp, 2013). Поменути модел критикован је такође јер је довео до обустављања традиционалних релација између људи и еко-система и права аутохтоног становништва на егзистенцијално коришћење природних ресурса са циљем опстанка (Stevens, 1997). На основу теренског истраживања на примеру НП Ђердап, аутор Кочовић наводи сличне проблеме који су пратили локалну заједницу. Наиме, НП Ђердап је проглашен тек након изградње Хидроелектране на Дунаву, која је заувек променила ток Дунава имплицирајући нестанак миграторних врста. Такође, богато културно наслеђе које је сведочило миленијуме остало је „заувек конзервирано” испод Дунава, јер је ниво реке порастао за 20 м у просеку. Хидроелектрана Ђердап, иако је обезбедила нова радна места, утицала је на промену микроклиме, па су дотадашњи мали (тзв. Small scale) бизниси нестали. У оквирима данашње територије Националног парка Ђердап, постојала су два острва чије становништво је више пута исељавано због потапања. Острва су потопљена, а становништво и након четрдесет година пати због те чињенице. На основу интервјуа са запосленима у туристичким организацијама и аутохтоним становништвом, може се закључити да је изградња Хидроелектране Ђердап, великог међународног пројекта, донела велике штете у погледу на: друштво, културу и еколошка питања. Иако је хидроелектрана обезбедила енергетску стабилност и велики број радних места, дискутабилно је да ли би Национални парк Ђердап могао да задржи статус у случају да се проглашење десило пре изградње хидроелектране.

Партиципативно управљање, према свему наведеном, представља добру алтернативу постојећем моделу управљања, јер може да обезбеди и већу интегративност у управљању природним и културним наслеђем, које ужива посебну заштиту. Комонсима покрива- 
мо значај, значење и сличности које важе за природно и културно наслеђе, које су више него очигледне:

а. Обе врсте наслеђа спадају у категорије заједничких, јавних и мешовитих добара;

б. То значи да ова добра припадају свима и да је неопходно обезбедити њихов дугорочни опстанак, као и то да њима могу управљати различити сектори.

Односи између културе и животне средине су нераскидиви и једноставније их је сагледати кроз људско стваралаштво и деловање. Природа представља својеврсну и непресушну инспирацију за стваралаштво, док стваралаштво човека у садејству са природом поново ствара нову културу, ослањајући се на постојећу.

Због тога природно и културно наслеђе, као јединствени и аутентични комонси, представљају најдубљу везу са припадношћу (локално, регионално, национално посматрано) и идентитетом људи, па је неопходно да управљачко решење буде што више могуће интегративно у погледу односа човек-култура-природа.

У прилог другим могућностима у погледу на финансирање, употребу и управљање националним парковима, кроз укључивање већег броја учесника различитих сектора, посебно локалне заједнице, иде то што комонси јесу неизоставни делови у оквирима територије националних паркова. Тачније, значајно је стављање комонса у однос са заштићеним подручјима, за које је пожељно управљање од стране заједнице. Надовезујући се на претходно, неки аутори (Kitamura \& Clapp 2013) предлажу управљачки оквир CPPA - common property protected areas. Наиме, стављањем у однос елемената као што су: право на употребу, начин експлоатације, уобичајене форме које произлазе из легислативе и теорије, односно инклузивност према рестриктивности у погледу на употребу, поменути аутори предлажу комбиновани оквир у погледу на заштићена подручја у којима локална заједница треба имати важну улогу и користи. Поменуто истраживање доводи у везу предлагање нових системских решења кроз комбиновани приступ управљачких решења како би одрживост националних паркова (као заштићених подручја) и припадајућег природног и културног наслеђа (као комонса) била осигурана, а на добробит локалне заједнице и економије.

У том смислу, ауторка Кочовић у свом докторату (Кочовић, 2017) предлаже ново системско решење за управљање заштићеним подручјима и еко-културним туризмом, као одговорном формом туризма ослоњеним на реално природно и културно наслеђе (комонсе). Предложено ново системско решење састоји се од препорука које за циљ имају да позитивно доприносе и обезбеде одрживи развој заштићених подручја и комонса. Моделовањем је интегрисана идеја да створене вредности које су ослоњене на постојеће треба да остану 
везане на локалном нивоу, стварајући користи примарно за аутохтоно становништво. Препоруке које се тичу новог системског решења поседују велики број елемената универзалности, па се може сматрати да су применљиве на разне врсте заштићених подручја и комонса:

1. партиципативно управљање;

2. формулисање нових производа заснованих на природном и културном наслеђу - еко-културне руте и путеви;

3. управљање ризицима природног и културног наслеђа и посетама (Кочовић, 2017).

\section{ЗАКЉУЧАК}

У првом делу рада објашњен је значај националних паркова као заштићених подручја и припадајућег наслеђа као комонса. Циљ се првенствено огледао у указивању на проблеме који се јављају у вези са релевантним феноменима. Поменути проблеми отворили су изазове у погледу на практично политичке управљачке опције и финансирање. У другом делу рада спроведена је компаративна анализа финансијских показатеља националних паркова Србије са циљем сагледавања финансијског положаја НП Ђердап и могућих изазова у вези са његовом економском одрживошћу. Питања и дискусије које су се отвориле у вези са финансијском анализом и управљачким опцијама националног парка као јавног предузећа имплицирала су дискусију и закључивање у неколико смерова:

1) Будући да је дугорочна финансијска одрживост један од највећих изазова за националне паркове у Србији, закључили смо да је то један од аргумената за озбиљно разматрање нових системских решења управљања и финансирања НП, као заштићених подручја и припадајућих комонса.

2) Ни краткорочна ни дугорочна финансијска стабилност не може свој ослонац црпети највећим делом из природних ресурса.

3) Закључујемо да правци развоја новог системског решења морају обухватити веће учешће локалне заједнице и свих заинтересованих страна. У том смислу, позивамо се на већи број теорија и претходних истраживања аутора овог рада. Партиципативно управљање са неколико потпорних препорука је елаборирано у трећем делу рада, које за циљ имају успостављање новог етичнијег, ефективнијег и ефикаснијег системског решења у односу на постојеће. На тај начин допринос препорука можемо сматрати вредним у погледу на: успостављање дугорочне финансијске стабилности, употребу и управљање заштићеним подручјима и припадајућим комонсима, на примеру НП Ђердап.

Резултати овог истраживања могу бити сматрани добрим аргументом за даље преиспитивање и проналажење алтернативе у фи- 
нансирању и управљању, која ће обезбедити веће хоризонтално повезивање свих сектора, али и блиских ресора и дати допринос одрживом развоју националних паркова.

\section{ЛИТЕРАТУРА}

Barnes, P. (2006). Capitalism 3.0: A guide to reclaiming the commons. BerrettKoehler Publishers.

Colchester, M. (1996). Beyond "participation": indigenous peoples, biological diversity conservation and protected area management. UNASYLVA-FAO-, 33-39.

Cronon, W. (1995). Uncommon ground: toward reinventing nature (Vol. 95). New York: Norton.

Eagles, P. F., McCool, S. F., Haynes, C. D., Phillips, A., c United Nations Environment Programme (Cambridge, Great Britain). (2002). Sustainable tourism in protected areas: Guidelines for planning and management (Vol. 8). Gland: IUCN.

García-Frapolli, E., Ramos-Fernández, G., Galicia, E., \& Serrano, A. (2009). The complex reality of biodiversity conservation through Natural Protected Area policy: Three cases from the Yucatan Peninsula, Mexico. Land Use Policy, 26(3), 715-722.

Hazen, H.D., \& Harris, L.M., (2007). Limits ofterritorially-focused conservation: a critical assessment based on cartographic and geographic approaches. Environmental Conservation 34 (4), 280-290.

Hess, K., 2001. Parks are for people - but which people? In: Anderson, T.L., James, A. (Eds.), The Politics and Economics of Park Management. Rowman \& Littlefield, Lanham, pp. 159-181

Holdgate, M. (1999). The Green Web - A Union for World Conservation. Earthscan, London.

IUCN (2008). Guidelines for Applying Protected Area Management Categories. IUCN, Gland, Cambridge, from IUCN: https://cmsdata.iucn.org/downloads/ uicn_categoriesamp_eng.pdf

IUCN. (1994). Guidelines for Protected Area Management Categories. IUCN, Gland, Cambridge.

Kitamura, K., \& Clapp, R. A. (2013). Common property protected areas: Community control in forest conservation. Land use policy, 34, 204-212.

Кочовић, М. (2017). Допринос еко-културног туризма одрживом развоју заштићених подручја са припадајућим природним и културним наслеђем [The contribution of eco-cultural tourism to sustainable development of protected areas with associated natural and cultural heritage phd thesis] (докторска теза), Факултет драмских уметности, Београд.

Kočović, M. (2015) The role of protected areas in managing catastrophic risks and contribution to sustainable development. Catastrophic risks and sustainable development, Belgrade: Faculty of Economics, Publishing Centre.

Kočović, M.., \& Đukić, V. (2015). Partnership as a strategy to achieve optimal participatory governance and risk mitigation (of cultural and natural heritage), The ENCATC Journal of Cultural Management and Policy.

Кривошејев, В. (2014). Управљање баштином и одрживи туризам [Managing heritage and sustainable tourism], Народни музеј Ваљево: http://mladizaturizam. org.rs/wp-content/uploads/2014/10/Upravljanje-bastinom-i-odrzivi-turizamVladimir-Krivosejev-bzkt.pdf

Лукић, Р. (2010) Рачуноводство осигуравајућих компанија [Accounting in insurance companies], Економски факултет Универзитета у Београду, Београд. 
Малешевић, Ђ., \& Вранковић, М. (2007). Пословна анализа [Business analysis], Економски факултет Суботица.

Mattei, U. (2011). Beni Comuni: Un Manifesto. Gius. Laterza \& Figli: Bari, Italy

Neumann, R. (1999). Imposing Wilderness. University of California Press, Berkeley

Ostrom, E. (2009). A general framework for analyzing sustainability of socialecological systems. Science 325(5939), 419-422

Phillips, A. (2004). Turning Ideas on Their Head: The New Paradigm For Protected Areas, Environmental History, 9(1), 173-197.

Poteete, A., \& Ostrom, E. (2004). Heterogeneity, group size and collective action: the role of institutions in forest management. Development and Change 35, 435-461.

Родић, J. (1991) Пословне финансије и процена вредности предузећа [Business finances and company value esstimation], Економика, Београд.

Stevens, S. (1997). The legacy of Yellowstone. In: Stevens, S. (Ed.), Conservation through Cultural Survival: Indigenous Peoples and Protected Areas. Island Press, Washington, DC 13-32.

Тушевљак, С., \& Родић, J. (2003). Финансије предузећа [Business finances]. Consseco institut.

Zimmerer, K.S. (2000). The reworking of conservation geographies: nonequilibrium landscapes and nature-society hybrids. Annals of the Association of American Geographers 90, 356-369.

\title{
CHALLENGES AND ALTERNATIVES RELATED TO FINANCIAL ANALYSIS AND MANAGEMENT OPTIONS FOR ACHIEVING SUSTAINABLE DEVELOPMENT OF PROTECTED AREAS AND COMMONS IN SERBIA
}

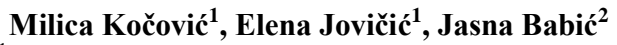 \\ ${ }^{1}$ Institute of Economic Sciences, Belgrade, Serbia \\ ${ }^{2}$ University of Belgrade, Faculty of Economy, Belgrade, Serbia
}

Summary

The theoretical basis of this work relies on a new theory of sustainable development as a concept and part of broader the paradigm - sustainability. The discussion in this paper opened space in conjunction to the relevant phenomena: national parks and heritage (as examples of protected areas and the commons).

The paper is also supported by previous comprehensive work and field research conducted by the author Kočović for the need of her PhD and the case of NP Djerdap. We took into consideration some aspects of the legal-political approaches regarding the protection and management of areas and heritage. With the help of financial analysis that was based on the indicators, which establish functional relationships among certain positions of the balance sheet and income statement, we were able to obtain a reliable estimation of the financial position for the observed national park on the basis of comparative analysis. Financial reports served as secondary input data for the analysis (of national parks in Serbia). These reports are publicly available on the website of APR (APR, 2016). 
In terms of practical examples on management of protected areas, especially important for this paper were examples of author Krivošejev, as well as theoretical ideas and directions of the author Ostrom in the context of commons.

Participatory forms of governance are seen as a desirable framework for the alternative system solutions. PG could positively contribute to establishment of the favorable conditions, for the local community benefits. Modeling of the new system solution with the intention to provide an integrated system for sustainable development through management of protected areas and associated commons was recognized as an effective way to solve problems. The leitmotif of the future system solutions should ensure that generated values remain tied to the local level, creating benefits primarily for the indigenous population.

The recommendations concerning the new system solutions have a number of the elements of universality. They could be considered as applicable for various types of protected areas and the commons:

1. Participatory governance;

2. Formulation of new products based on natural and cultural heritage - the ecocultural routes and roads;

3. Risk and visitor management of natural and cultural heritage (Kočović, 2017).

Participatory governance can be interpreted as a process that allows a shared responsibility for management model. Whereas, responsibility and decisions that are made concerning the community, not individuals. Such a model allows greater community participation by different actors (better linkage of sectors), through various forms of partnerships (Kočović, 2017).

The risks are jeopardizing sustainable development of the whole economy (economy, society, environment, culture) by caused damages. Due to the increasing intensity and frequency, catastrophic risks are a challenge of global proportions, whether caused by natural or human factor. Risk management in the sense of commons, in start operates with problems for at least two reasons. The first reason lies in the fact that Serbia is a country with low income. This situation is a natural barrier to think about preventive measures. The second and even more complex reason is given by author Kočović as a metaphoric example that refers to the problem of determining the value of cultural heritage. Kočović stated that the assessment of the value of cultural heritage is as difficult as evaluation of emotional pain and suffering in insurance (Kočović 2015; 2017). Determining the values of commons (natural and cultural public/commons) is equally difficult task to the aforementioned metaphor, since commons involve a large range of intangible values. The new form of insurance assumes formation of pools of insurance for commons, as a participatory form of insurance with mixed finance model (Kočović, Đukic 2015; Kočović 2017).

Besides the initial character of routes as primarily connectors because of socioeconomic benefits for people who have used them (hunting, fishing, trade, research, pilgrimages, etc.), with the relocation of the original context of roads and routes, it is possible to add new meanings and values (recreation, sports, cultural and historical revival, enjoying outings, holidays, etc.). It is possible to reformulate the recommendation for this survey research in: all responsible economic activities that contribute to the activation and preservation of commons within the protected areas.

Visitor management, in terms of protected areas and associated commons represents combination of preventive and control measure, limiting the movement or use of the most vulnerable, non-renewable or slowly renewable commons. When we talk about visitor management within the protected area, this concept is closely related to the risk management, because both rely on mitigation of potential harmful effects. The third recommendation is particularly important as an aspect of the overall participatory management of protected areas and associated commons. 